\title{
STATUS UANG APBN YANG DIPISAHKAN DAN DIJADIKAN PENYERTAAN MODAL PADA BUMN PERSERO
}

\author{
David Putra Timbo ${ }^{1}$, Peter Mahmud Marzuki ${ }^{2}$
}

\begin{abstract}
ABSTRAK
Secara yuridis, modal yang disertakan ke dalam perseroan bukan lagi menjadi kekayaan orang menyertakan modal, tetapi menjadi kekayaan perseroan itu sendiri. Hal tersebut terjadi pemisahan kekayaan antara kekayaan pemegang saham dan perseroan. Berkaitan dengan di persangkakan dan dituntutnya sejumlah mantan direksi atau direksi PT BUMN (Persero) atas perbuatan mereka yang merugikan PT BUMN (Persero) sehingga dikategorikan merugikan keuangan negara, perlu diberikan pemahaman mendalam karena keuangan PT BUMN (Persero) berdasarkan teori hukum dan teori lingkungan kuasa hukum bukan merupakan keuangan negara sehingga kerugian pada PT BUMN (Persero) bukan kerugian negara.
\end{abstract}

Kata Kunci: Keuangan Negara.

\begin{abstract}
Legally, the capital that came into the company no longer includes a wealth of capital, but a wealth of the company itself. It is a separation of wealth between shareholders and corporate wealth. In connection with the allegation and demanded in a number of former directors or directors of State Owned Enterprises for their acts detrimental to State Owned Enterprises to be considered detrimental to the state, should be given in depth understanding as financial SOEs based on legal theory and the theory of power law is not a financial loss to the state, so that the State Owned Enterprises is also not harm the country.
\end{abstract}

Keywords : State Finances

\footnotetext{
${ }^{1}$ Mahasiswa Program Studi Magister Ilmu Hukum UNDIP

${ }^{2}$ Dosen Program Studi Magister IImu Hukum UNDIP
} 


\section{A. PENDAhuluan}

1. Latar Belakang

Pelaksanaan pengelolaan keuangan negara selama ini masih menggunakan ketentuan perundang-undangan yang disusun pada masa pemerintahan kolonial Hindia Belanda yang berlaku berdasarkan Aturan Peralihan UndangUndang Dasar 1945, yaitu IndischeComptabiliteitswet yang lebih dikenal dengan nama ICW Stbl. 1925 Nomor 448 terakhir Undang-Undang Nomor 9 Tahun 1968 yang ditetapkan pertama kali pada tahun 1864 dan mulai berlakupada tahun 1867, Indische Bedrijvenwet yang lebih dikenal dengan nama IBW Stbl. 1927 Nomor419 jo. Stbl. 1936 Nomor 445 dan Reglement voor het Administratief Beheer (RAB) Stbl. 1933 Nomor 381. Peraturan perundang-undangan tersebut tidak dapat mengakomodasikan berbagai perkembangan yang terjadi dalam sistem kelembagaan negara dan pengelolaan keuangan pemerintah negara Republik Indonesia.

Pemikiran aparat penegak hukum Kejaksaan Agung, Kepolisian dan Pemeriksa BPK, bahwa kerugian persero merupakan kerugian negara tidaklah salah. Landasan hukum yang mendasari pemikiran tersebut adalah Undang-Undang Nomor 17 Tahun 2003 tentang Keuangan Negara dimana Pasal 1 angka 1. Pada sisi kalangan akademisi dan juga Direksi Persero berpendapat bahwa pengaturan BUMN Persero sebagai Perseroan Terbatas tunduk pada Undang-Undang Nomor 19 Tahun 2003 tentang BUMN, dan Undang-Undang Nomor 1 Tahun 1995 tentang Perseroan Terbatas sebagaimana telah diganti dengan UndangUndang Nomor 40 Tahun 2007 tentang Perseroan Terbatas, bahwa kerugian persero adalah merupakan kerugian persero sebagai badan hukum (legal person), dan bukan merupakan kerugian negara

2. Metode Penelitian

Di dalam penelitian hukum terdapat beberapa pendekatan, 


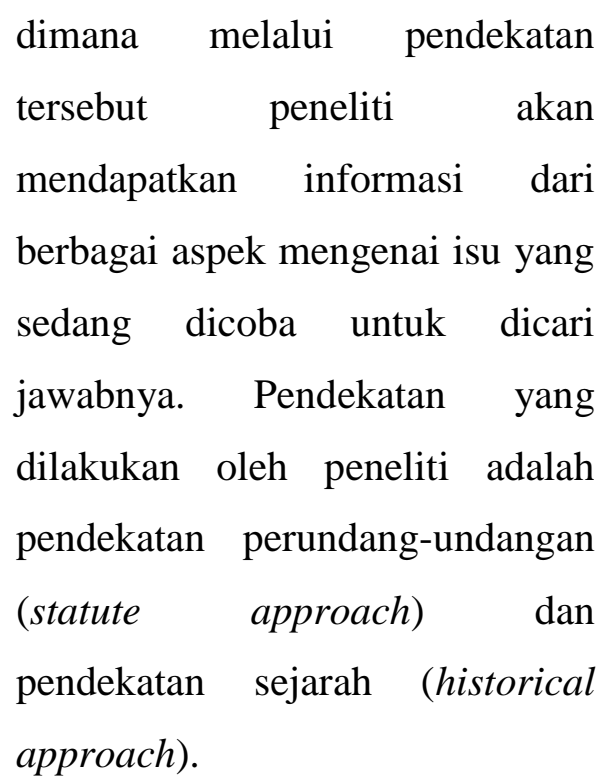

3. Kerangka Teori

Perseroan terbatas sebagai badan hukum perdata (privat) yang mempunyai status kemandirian (persona standi in judicio) sudah tentu memiliki identitas hukum sendiri. Identitas hukum suatu korporasi atau perusahaan terpisah dari identitas hukum para pemegangsahamnya, direksi, maupun organ-organ lainnya. Kajian penelitian tesis ini akan menyangkut tentang; Teori Badan Hukum dan Teori Pertanggung Jawaban Direksi.

\section{B. HASIL PENELITIAN DAN PEMBAHASAN}

1. Status Uang APBN Yang
Dipisahkan Dan Dijadikan Penyertaan Modal

a. Keuangan Negara
Sebagai sumber pembiayaan terhadap pelaksanaan tugas negara, terlebih dahulu dipahami pengertian keuangan negara. Hal ini dimaksudkan agar tidak terdapat kesalahpahaman mengenai substansi yang terkandung dalam keuangan negara. Sebagai pedoman ada beberapa definisi tentang keuangan negara dapat dikelompokkan:

1) Pakar hukum berdasarkan kompetensi keilmuannya;

Menurut M. Ichwan yang dimaksud keuangan negara adalah rencana kegiatan secara kuantitatif, yang akan dijalankan untuk masa mendatang, lazimnya satu tahun mendatang. Berdasarkan pengertian keuangan menurut M. Ichwan tersebut, penulis berpendapat bahwa M. Ichwan menunjuk keuangan negara dari sudut pandang proses karena hanya menyangkut pengelolaan keuangan negara. Sehingga pendapat M. Ichwan tentang keuangan negara tersebut 
tidak mendefinisikan keuangan negara, tetapi lebih memandang pengertian anggaran negara.

Menurut Peter Mahmud Marzuki yang dimaksud keuangan negara adalah dana yang dimiliki oleh negara dalam rangka menjalankan kegiatan publik. Dengan pengertian demikian, uang yang diinvestasikan ke suatu badan hukum untuk kegiatan yang tunduk kepada hukum privat bukan lagi keuangan negara, melainkan keuangan badan hukum tersebut; sama halnya dengan seorang yang melakukan investasi ke suatu PT, uang orang tersebut sudah menjadi uang PT itu. Berdasarkan pengertiankeuangan negara menurut Peter Mahmud Marzuki tersebut, maka dapat penulis simpulkan keuangan negara merupakan dana yang dimiliki negara untuk menjalankan kegiatan publik, apabila keuangan negara masuk dalam badan hukum privat sebagai penyertaan modal, maka keuangan negara bukan lagi milik negara melainkan milik badan hukum privat tersebut. Hal ini dikarenakan adanya perubahan fungsi dan transformasi status yaitu yang semula digunakan untuk publik menjadi digunakan untuk kepentingan badan hukum privat dan status uang negara tersebut menjadi uang badan hukum privat.

Menurut penulis pengertian keuangan negara, yaitu kekayaan negara baik berupa barang maupun uang, dimana keuangan negara ini di gunakan untuk kepentingan publik. Apabila pemerintah melakukan penyertaan modal uang negara yang di ambil dari APBN ke badan hukum privat, fungsi uang negara tersebut sudah berubah dari untuk kepentingan publik menjadi kepentingan badan hukum privat. Hal ini di karenakan uang negara yang sudah masuk ke dalam badan hukum privat menjadi milik badan hukum privat seutuhnya.

2) Undang-undang.

Definisi yang terdapat dalam Pasal 1 angka 1 UU Keuangan Negara menggunakan pendekatan luas, dengan tujuan terdapat perumusan definisi keuangan negara secara cermat dan teliti untuk mencegah terjadinya multi interpretasi dalam segi pelaksanaan anggaran supaya tidak terjadi kerugian negara sebagai 
akibat kelemahan dalam perumusan undang-undang dan memperjelas proses penegakan hukum apabila terjadi penyalahgunaan administrasi dalam pengelolaan keuangan negara.

Undang-undang nomor 1 tahun 2004 tentang perbendaharaan negara dimaksudkan untuk memberikan landasan hukum di bidang administrasi keuangan negara. Pada pasal 1 angka 1 tidak terdapat secara spesifik pengertian lebih lanjut tentang keuangan negara yang harus dipertanggungjawabkan, namun terdapat kata-kata "termasuk investasi dan kekayaan yang dipisahkan”. Demikian pula dalam penjelasan umum disebutkan. Jika mengacu pada pengertian ini, maka menurut Undang-Undang Nomor 1 tahun 2004 tersebut, semua kekayaan yang berasal dari kekayaan negara yang dipisahkan termasuk dalam lingkup pengelolaan dan pertanggungjawaban negara.

Undang-Undang BUMN pertama kali diterbitkan pertama kali oleh pemerintah pada tahun 1960 berupa Perpu Nomor 19 Tahun 1960 tentang Perusahaan Negara. Perpu ini diterbitkan dengan tujuan mengusahakan adanya keseragaman dengan cara mengurus dan mengusai serta bentuk hukum dari badan usaha negara yang ada. Dalam Perpu yang dimaksud dengan perusahaan negara adalah semua perusahaan dalam bentuk apapun yang modalnya untuk seluruhnya merupakan kekayaan negara Republik Indonesia, kecuali jika ditentukan lain dengan atau berdasarkan Undang-Undang.

3) Keuangan Negara Menurut Fatwa

Mahkamah Agung Republik Indonesia Pada tanggal 16 Agustus 2006, Mahkamah Agung RI melalui keputusan No.

\section{WKMA/Yud/20/VII/2006}

mengeluarkan fatwa tentang Tata Cara Penghapusan Piutang Negara yang menyatakan bahwa piutang BUMN tidak dapat disebut piutang negara. Fatwa MA ini diterbitkan sebagai jawaban atas permintaan pendapat hukum dari Menteri Keuangan RI melalui surat nomor $S$ 324/MK.01/2006 pada tanggal 26 Juli 2006.

Berdasarkan fatwa Mahkamah Agung tersebut, terlihat jelas bahwa 
terjadi perubahan fungsi dan transformasi status hukum kekayaan/keuangan negara dalam BUMN dari kewenangan (taak en bevoegdheid) sebagai badan hukum publik menjadi

hak dan kewajiban sebagai akibat transaksi horisontal dan transformasi status hukum uang negara menjadi uang perdata, yang hakikatnya menjadi dasar yang kuat untuk menguatkan hak dan kewajiban BUMN (Persero) sebagai badan hukum.

Berdasarkan fatwa mahkamah agung tersebut, bahwa modal BUMN berasal dari kekayaan negara yang telah dipisahkan dari APBN dan selanjutnya pembinaan dan pengelolaannya tidak didasarkan pada sistem APBN melainkan didasarkan pada prinsip-prinsip perusahaan yang sehat, maka BUMN (Persero) tersebut harus tunduk kepada Undang-Undang Nomor 40 Tahun 2007 tentang Perseroan Terbatas sebagaimana diatur dalam 4 UU Nomor 40 tahun 2007 tentang Perseroan Terbatas.

Dengan adanya pemisahan kekayaan sebagaimana dinyatakan dalam Pasal 4 UU BUMN, seharusnya piutang yang terdapat pada BUMN sebagai akibat perjanjian yang dilaksanakan oleh BUMN selaku entitas perusahaan tidak lagi dipandang sebagai piutang negara. Pengelolaan termasuk pengurusan atas piutang BUMN tersebut, tidak dilakukan dalam koridor pengurusan piutang negara melainkan diserahkan kepada mekanisme pengelolaan berdasarkan prinsip-prinsip perusahaan yang sehat berdasarkan peraturan perundang-undangan yang berlaku. Berdasarkan pemikiran tersebut, maka BUMN memiliki kewenangan dalam mengoptimalkan pengelolaan pengurusan atau penyelesaian piutang yang ada pada BUMN yang bersangkutan, sehingga pengaturan Penghapusan Piutang Perusahaan Negara atau Daerah yang ada pada Peraturan Pemerintah Nomor 14 Tahun 2005 saat ini menjadi tidak diperlukan lagi. ${ }^{3}$

b. Penyertaan modal negara pada

\footnotetext{
${ }^{3}$ Erman Rajagukguk, "Pengertian Keuangan Negara dan Kerugian Negara", makalah disampaikan pada peran BUMN dalam Mempercepat Pertumbuhan Perekonomian Nasional, Jakarta, 12-13 April 2007.
} 


\section{BUMN Persero}

Penyertaan modal adalah pemisahan kekayaan negara dari Anggaran Pendapatan dan Belanja Negara atau penetapan cadangan perusahaan, dan dikelola secara korporasi. Sumber Penyertaan Modal Negara pada BUMN tersebut berasal dari Anggaran Pendapatan dan Belanja Negara, kapitalisasi cadangan, dan/atau sumber lainnya. Sumber penyertaan modal negara yang berasal dari Anggaran dan Pendapatan Belanja Negara berupa dana segar, proyekproyek yang dibiayai dari Anggaran Pendapatan dan Belanja Negara, piutang negara pada BUMN atau Perseroan Terbatas serta aset-aset negara lainnya berupa keuntungan revaluasi aset dan/atau agio saham.

c. Konsepsi kekayaan Negara Yang Dipisahkan Dalam Perusahaan Perseroan

Secara yuridis, modal yang disertakan ke dalam perseroan bukan lagi menjadi kekayaan orang menyertakan modal, tetapi menjadi kekayaan perseroan itu sendiri. Jelas bahwa berdasarkan hal tersebut terjadi pemisahan kekayaan antara kekayaan pemegang saham dan perseroan. Dengan karakteristik tersebut, maka tanggung jawab pemegang saham atas kerugian atau utang perseroan juga terbatas. Utang atau kerugian tersebut semata-mata dibayar secukupnya dari harta kekayaan yang tersedia dalam perseroan.

d. Perbandingan ICW Dengan Undang-Undang Nomor 17 Tahun 2003 tentang Keuangan Negara dan IBW Dengan Undang-Undang 19 Tahun 2003 tentang Badan Usaha Milik Negara

Pada zaman pemerintah kolonial Belanda, keuangan negara diatur dalam IndischeComptabiliteitswet yang lebih dikenal dengan nama ICW Stbl. 1925 Nomor 448 yangmengatur tentang tata pembukuan yang harus dilakukan oleh para pejabat yang melakukan pengurusan keuangan baik di tingkat Departemen Keuangan maupun di Departemen teknis, dan secara khusus mengatur kewenangan di sisi kebendaharaan. Pencatatan atau pembukuan yang didasarkan pada ketentuan ICW Bab I Bagian 4 dan Bagian 5 diharapkanakan mampu menghindari penggelapan atau 
penipuan yang berhubungan dengan keuangan (financial fraud) yang mungkin dilakukan oleh para pejabat pada saat itu. Selain pencatatan atau pembukuan juga mengatur tentang kewenangan di sisi kebendaharaan yaitu wewenang untuk melakukan tindakan-tindakan yang akan membawa ke arah penerimaan atau pengeluaran negara yang dilakukan oleh Pemerintah yang bertindak sebagai Otorisator sebagaimana dimaksud dalam Pasal 25 ICW dan wewenang untuk melaksanakan tugas pekerjaan yang dilakukan oleh Presiden atau Pembantu-Pembantunya bertindak sebagai Ordonanteur meliputi menerima tagihan yang diajukan kepada negara atas beban APBN, meneliti dan menguji keabsahan tagihan tersebut, dan menerbitkan surat perintah membayar sebagaimana dimaksud dalam Pasal 35, Pasal 36, Pasal 39, Pasal 40 dan Pasal 41 ICW.

Sedangkan pada zaman setelah kemerdekaan, keuangan negara diatur dalam Undang-Undang No. 17 Tahun 2003 tentang Keuangan Negara yang mengatur peran lembaga Legislatif dan lembaga Eksekutif dalam penyusunan dan penetapan APBN menjadi Undang-Undang, kejelasan peran tersebut merupakan suatu keharusan untuk menjamin terselenggaranya transparansi di bidang penganggaran. Lahirnya Undang-Undang No. 17 Tahun 2003 tentang Keuangan Negara telah menjadikan perubahan yang mendasar dalam system perencanaan dan penganggaran yaitu perubahan pola keuangan negara yang sebelumnya Publik Financial Adminstration menjadi Publik Financial ManagementI.

Perubahan-perubahan yang terjadi pada pengelolaan keuangan negara adalah perubahan dalam hal perencanaan dan penyusunan anggaran, pelaksanaan anggaran, serta sampai dengan pemeriksaan perubahan keuangan negara yang dilakukan oleh Badan Pemeriksa Keuangan.

Pada zaman pemerintah kolonial Belanda, perusahaan negara diatur dalam IndischeBedrijvenwet yang lebih dikenal dengan nama IBW Stbl. 1927 Nomor 419 mengatur tentangbeberapa hal yaitu ; anggaran perusahaan negara, modal perusahaan 
Negara, pemilikan perusahaan negara, penerimaan dan pengeluaran perusahaan negara, beban-beban dan keuntungan-keuntungan eksploitasi perusahaan negara, perhitungan tahunan dari perusahaan-perusahaan negara kepala-kepala departemendepartemen pemerintahan dalam waktu empat bulan setelah tahun pembukuan mengirimkan perhitunganperhitungan tahunan dari perusahaanperusahaan negara yang termasuk kementerian mereka masing-masing kepada pemerintah.

Sedangkan pada zaman setelah kemerdekaan, perusahaan negara diatur dalam Undang-Undang No. 19 Tahun 2003 tentang Badan Usaha Milik Negara mengatur tentang beberapa hal yaitu; definisi, maksud dan tujuan, modal, jenis-jenis perusahaan negara, penggabungan, peleburan, pengambilalihan, dan Pembubaran BUMN, dan kewajiban pelayanan umum

2. Pemberlakuan Undang-Undang Nomor 19 Tahun 2003 tentang BUMN bagi BUMN Persero

Organ BUMN Persero sama seperti yang diatur dalam Undang-
Undang Nomor 40 Tahun 2007 tentang Perseroan Terbatas, oleh karena itu BUMN Persero pada hakekatnya adalah Perseroan Terbatas. Organ BUMN Persero yaitu meliputi RUPS, Direksi, dan Dewan Komisaris. Rapat Umum Pemegang Saham, yang selanjutnya disebut RUPS.

Adapun yang membedakan antara organ Perseroan Terbatas dengan organ BUMN Persero terletak pada pemegang sahamnya. Pada BUMN Persero pemerintah dapat bertindak selaku RUPS apabila seluruh sahamnya dimiliki oleh negara, sementara apabila pemerintah terlibatdalam penyertaan modal negara (PMN) sebagian, maka kedudukan pemerintah adalah sebagai salah satu pemegang saham.

Pada BUMN Persero modal yang disertakan oleh pemerintah merupakan dan berasal dari kekayaan negara yang dipisahkan. Penyertaan negara dalam rangka pendirian atau penyertaan modal pada BUMN Persero salah satunya bersumber dari Anggaran Pendapatan dan Belanja Negara, selain dari kapitalisasi cadangan dan sumber lainnya. penyetoran atas modal saham 
dapat dilakukan dalam bentuk uang dan / atau dalam bentuk lainnya.

UU BUMN telah mengadopsi beberapa prinsip Good Corporate Governance, hal ini dinyatakan pada Pasal 36 ayat (1) UU BUMN yang menyatakan bahwa Perum dalam menyelenggarakan usahanya harus berdasarkan pada prinsip pengelolaan perusahaan yang sehat. ${ }^{4}$ Ketentuan tersebut juga diatur dalam Pasal 5 ayat (3) jo. Pasal 6 ayat (3) UU BUMN.

3. Persangkaan Direksi BUMN Persero Melakukan Tindakan Korupsi Dalam Menjalankan Transaksi Bisnis Yang Diduga Dapat Merugikan Keuangan Negara Penyidikan perkara yang dilanjutkan dengan penuntutan di pengadilan tidak lepas dari pemahaman para penyidik dan penuntut umum terhadap status keuangan PT BUMN (Persero) dan status direksinya. Penyidik dan penuntut umum memandang keuangan PT BUMN (Persero) merupakan keuangan negara dan direksi PT BUMN (Persero)

${ }^{4}$ Bismar Nasution, Mengukur Kinerja Direktur BUMN, makalah, hlm. 1 merupakan pegawai negeri atau penyelenggara negara. Oleh karena itu, jika terjadi kerugian pada PT BUMN (Persero) maka kerugian tersebut merupakan kerugian negara dan terhadap direksi PT BUMN (Persero) dianggap penyelenggara negara sehingga dapat di pidana korupsi.

Sebagai badan hukum privat tersendiri dari manapun asal modal yang diberikan, ketika sudah dimasukkan ke dalam PT BUMN (Persero), maka modal tersebut sudah merupakankekayaan BUMN sebagai hukum mandiri yang kemudian pengelolaan modal tersebut tunduk pada lingkungan kuasa hukum privat.

Selanjutnya M. Yahya Harahap menyatakan, pemegang saham sebagai pemilik, hanya mempunyai hak kontrol tidak langsung atas operasional sehari-hari perseroan dan atas segala kebijaksanaan direksi. Akan tetapi pemegang saham tidak memikul tanggung jawab atas pelaksanaan fungsi-fungsi direksi. Semakin banyak saham yang dimiliki seorang pemegang saham, semakin besar kekuasaan kontrol yang dapat 
dilakukannya, dimana tanggung jawab pemegang saham tidak bertanggung jawab secara pribadi atas perikatan yang dibuat atas nama perseroan melebihi saham yang dimiliki. $^{5}$

Berkaitan dengan di persangkakan dan dituntutnya sejumlah mantan direksi atau direksi PT BUMN (Persero) atas perbuatan mereka yang merugikan PT BUMN (Persero) sehingga dikategorikan merugikan keuangan negara, perlu diberikan pemahaman mendalam kepada para penyidik dan penuntut. Termasuk hakim yang akan mengambil keputusan terhadap perkara tersebut. Apabila penyidik dan penuntut mempersangkakan/ menuntut mereka dengan pasal 2 atau pasal 3 UU No. 31 tahun 1999 jo UU No. 20 tahun 2001 masing-masing pasal tersebut mengandung salah satu unsur pasalnya dapat merugikan negara, maka sesuai asas hukum pidana yang berlaku seharusnya direksi PT BUMN (Persero) dibebaskan. Hal tersebut

${ }^{5} \mathrm{M}$ Yahya Harahap, Separate Entity, Limited Liability, dan Piercing The Corporate Veil, Jurnal Hukum Bisnis, Volume 26 No. 3 Tahun 2007, hal. 44 karena keuangan PT BUMN (Persero) berdasarkan teori hukum dan teori lingkungan kuasa hukum bukan merupakan keuangan negara sehingga kerugian pada PT BUMN (Persero) juga bukan kerugian negara.

Pengenaan delik pidana korupsi yang salah satu unsur pasal berbunyi "merugikan keuangan negara" terhadap perbuatan melawan hukum/penyalahgunaan kewenangan yang dilakukan direksi PT BUMN (Persero) adalah tidak pada tempatnya. Secara garis besar pengenaan ini seharusnya tidak dilakukan berdasarkan teori badan hukum dan teori lingkungan kuasa hukum.

Berdasarkan alasan tersebut diatas apabila direksi PT BUMN (Persero) melakukan perbuatan melawan hukum dan akibatnya merugikan keuangan PT BUMN (Persero), maka direksi PT BUMN (Persero) tidak dapat dipersangkakan/ dituntut berdasarkan Pasal 2 atau Pasal 3 UU No. 31 tahun 1999 jo. UU No. 20 Tahun 2001. Oleh karena persangkaan maupun pendakwaan kepada direksi PT BUMN (Persero) tidak memenuhi tindak pidana, karena dalam hukum pidana 
berlaku asas umum bahwa apabila salah satu unsur pasal tidak terbukti maka unsur pasal lain tidak perlu dibuktikan dan tindak pidana tidak terpenuhi, sehingga terhadap terdakwa harusnya di bebaskan.

\section{Banyaknya PT BUMN (Persero)} yang mengalami kerugian atau tidak mendapatkan keuntungan semestinya menjadi problem utama bagi negara, sehingga negara memberikan subsidi ke PT BUMN (Persero) yang menguras kas negara. Kondisi tersebut tidak lepas dari masih melekatnya perilaku korupsi dalam pengelolaan PT BUMN (Persero) maupun orang diluar organ tetapi memiliki kemampuan untuk mempengaruhi direksi dan komisaris PT BUMN (Persero). Perilaku korupsi tersebut, berupa kolusi dengan pihak tertentu dalam pengadaan barang, investasi secara sembarang karena mendapatkan imbalan dari pihak yang diuntungkan, kolusi dengan perusahaan pesaing yang merugikan perusahaan, biaya keperluan pribadi yang dibayar perusahaan, manipulasi distribusi barang produksi, kongkalikong dalam penentuan proyek, pembocoran strategi perusahaan, dan lainnya. Memberantas perilaku korupsi dapat dilakukan dengan cara pencegahan (preventif) maupun penindakan (represif). Perilaku korupsiterjadi karena adanya niat dan kesempatan. Adapun niat bisa timbul karena adanya tekanan darikementerian BUMN sebagai pihak pengawas yang memiliki kemampuan untuk menentukankelangsungan jabatan direksi bersangkutan atau bisa juga dari diri direksi pribadi karenamoralitas yang jelek.

\section{SIMPULAN DAN SARAN}

1. Simpulan

Berdasarkan penelitian penulis terhadap tiga permasalahan dalam tesis, maka dapat dirumuskan kesimpulan sebagai jawaban atas tiga permasalahan penelitian sebagai berikut:

a. Secara yuridis penyertaan negara dalam BUMN (Persero) merupakan kekayaan negara yang di pisahkan, oleh karena itu kekayaan tersebut 
merupakan kekayaan

BUMN (Persero). Hal ini

disebabkan status uang

negara yang telah menjadi

saham terjadi transformasi

hukum dari "uang publik"

menjadi "uang privat".

b. Organ dalam BUMN Persero sebagaimana diatur dalam pasal 13 UU BUMN sama seperti yang diatur dalam Undang-Undang Nomor 40 Tahun 2007 tentang Perseroan Terbatas. Adapun yang membedakan antara organ Perseroan Terbatas dengan organ BUMN Persero terletak pada pemegang sahamnya. Pada BUMN Persero, pemerintah dapat bertindak selaku RUPS apabila seluruh sahamnya dimiliki oleh negara, sementara apabila pemerintah terlibat dalam penyertaan modal negara (PMN) sebagian, maka kedudukan pemerintah adalah sebagai salah satu pemegang saham.
Sehingga berdasarkan pada penjelasan tersebut dapat dikatakan bahwa PT BUMN (Persero) tunduk pada Undang-Undang No. 19 Tahun 2003 tentang Badan Usaha Milik Negara dan Undang-Undang No. 40 Tahun 2007 tentang Perseroan Terbatas.

c. Kekayaan PT BUMN (Persero) pengelolaannya tunduk pada lingkup kuasa privat, sehingga pengenaan delik pidana korupsi yang salah satu unsur pasal berbunyi "merugikan keuangan negara" terhadap perbuatan melawan hukum/penyalahgunaan kewenangan yang dilakukan direksi PT BUMN (Persero) adalah tidak pada tempatnya.

2. Saran

a. Pemerintah seharus menyadari bahwa BUMN (Persero) merupakan entitas bisnis yang tidak bisa lepas dari pengaruh pasar yang 
dinamis. Oleh karena itu kerugian yang dialami BUMN

(Persero) harus di pandang sebagai sesuatu yang wajar sepanjang pengurus BUMN (Persero) telah melaksanakan tata kelola perusahaan yang baik dalam mengurus BUMN (Persero).

b. Bagi pengurus BUMN (Persero) yang tidak melaksanakan tata kelola perusahaan yang baik sehingga menimbulkan kerugian bagi BUMN (Persero), pemerintah dapat mengatasinya dengan cara pemerintah sebagai pemegang saham dapat menggugat direksi atau komisaris BUMN (Persero) secara perdata, dan pemerintah dapat melaporkan pengurus BUMN (Persero) kepada aparat penegak hukum apabila diduga terjadi pemalsuan data dan laporan keuangan, penggelapan uang perusahaan, pelanggaran atas perundangan-undangan lain yang memuat ketentuan pidana dalam Kitab Undang-Undang Hukum Pidana.

\section{DAFTAR PUSTAKA}

Erman Rajagukguk, "Pengertian Keuangan Negara dan Kerugian Negara”, makalah disampaikan pada peran BUMN dalam Mempercepat Pertumbuhan Perekonomian Nasional, Jakarta, 12-13 April 2007. Bismar Nasution, Mengukur Kinerja Direktur $B U M N$, makalah

M Yahya Harahap, Separate Entity, Limited Liability, dan

Piercing The Corporate Veil, Jurnal Hukum

Bisnis, Volume 26 No. 3 Tahun 2007

Republik Indonesia.Undang-Undang Nomor 31 Tahun 1999, tanggal 16 Agustus 1999 jo Undang-Undang Nomor 20 Tahun 2001,tanggal tentang Pemberantasan Tindak Pidana Korupsi (Lembaran Negara Republik Indonesia Nomor 140 Tahun 1999)

Republik Indonesia. Undang-Undang Nomor 17 Tahun 2003, tanggal 5 April 2003 tentang Keuangan Negara, (Lembaran Negara Republik Indonesia Nomor 47 Tahun 
2003)

Republik Indonesia. Undang-Undang Nomor 19 Tahun 2003, tanggal 19 Juni 2003 tentang Badan Usaha Milik Negara, (Lembaran Negara Republik Indonesia Nomor 70 Tahun 2003)

Republik Indonesia, Undang-Undang Nomor 20 Tahun 2003, tanggal $21 \quad$ Nopember 2001tentang perubahan atas Undang-Undang Nomor 31 Tahun 1999 tentang Pemberantasan Tindak Pidana Korupsi. Republik Indonesia, Undang-Undang No. 32 Tahun 2004 tentang Pemerintah Daerah sebagaimana telah di ubah terakhir dengan UndangUndang No. 12 Tahun 2008 tentang Perubahan Kedua atas Undang-Undang No. 32 Tahun 2004 tentang Pemerintah Daerah.

Republik Indonesia, Undang-Undang Nomor 40 Tahun 2007, tanggal 16 Agustus 2007 tentang Perseroan Terbatas, (Lembaran Negara Republik Indonesia Nomor106 Tahun 2007)

http://id.wikipedia.org/wiki/

Badan Usaha Milik Negara

http://id.wikipedia.org/wiki/Anggara

n Pendapatan dan Belanja

Negara 